\title{
Chapter 8 \\ Forging the Needed Dialogue Between \\ Educational Leadership and Curriculum \\ Inquiry: Placing Social Justice, Democracy, and Multicultural Perspectives into Practice
}

\author{
Ira Bogotch, Dilys Schoorman, and Daniel Reyes-Guerra
}

\begin{abstract}
History demonstrates that the relationship between curriculum studies and educational leadership is mediated by the conceptualization of curriculum adopted within specific community contexts. To this end, we identify four conceptualizations of curriculum that have been effected in the USA and explore the varied relationship between our two fields that each context portends. Our analysis demonstrates that only when both fields of study have come together for the benefit of society, the common good, will the emergent leadership and curriculum result in progressive attempts at multiculturalism, democracy and social justice. Towards that end, we offer a developmental dialogical framework transitioning from relations grounded in stratification, homogenization, transformation, and the stage we call leadership for social justice. This progressive dialogue is ever more problematic, as it has to navigate multiple obstacles of temporal policies and politics as well as ideological divides. Thus, the complicated conversations are among those who seek to maintain old values and norms (e.g., stratification and homogenization) with those who take a counterview (transformation), or critical perspective (social justice).
\end{abstract}

\section{Overview}

In this chapter, we situate the histories of school leadership (a subfield of educational leadership) together with curriculum inquiry within a larger USA political, cultural, and economic context. To be clear, our two disciplines have been subject to direct and indirect control by external authorities from colonial times to the present. Our analysis demonstrates that when both disciplines have come together

I. Bogotch $(\bowtie) \cdot$ D. Schoorman $\bullet$ D. Reyes-Guerra Florida Atlantic University, Boca Raton, FL, USA

e-mail: ibogotch@fau.edu 
progressively for the benefit of society, then the emergent leadership and curriculum result in real attempts at social justice, democracy, and multiculturalism. Yet, when we accept the historical dominance and subjugation of our fields as a permanent state of affairs, then it makes no difference whether or not we communicate across disciplines. We will explain.

History confirms that our struggles today have been confronted in the past. History also confirms that how the struggles are conceptualized, as stratification, homogenization, transformation or as social justice, are effected by politics and policies, locally and nationally. Such dynamic challenges occur in all national contexts as a complex conversation. Our narrative specifically captures the unique characteristics of the complex conversation within the USA context.

As such, we are obligated by our history to acknowledge the diversity of the nation's populations, highlighting the waves of voluntary and involuntary immigration as well as the horrific treatment of the original occupants of our land, that is, Native Americans. Therefore, our national focus has to be viewed through the lenses of (1) multiculturalism as context, (2) democracy as relationships and an experiment, and (3) social justice as purposes and the struggles to obtain equitable ends of education. The three co-exist; that is, it cannot and should not be otherwise in the USA context. Hence, the necessity underlying our historical and contemporary arguments. At the same time, within each era from the 1600s to the present, new and different circumstances have influenced the struggles for human rights, economic rights, and the quality of life, adding a dimension of contingent and temporal realities to the narrative.

Our purpose here is to provide context: that is, our perception of the current USA reality, how we got here, and how we hope to begin complex conversations. We identify four conceptualizations of curriculum, explore the relationship between curriculum and leadership that each would create, and then discuss how this all can come together into a framework of future dialogue.

\section{Where We Are}

We first ask, how did the recorded USA history bring us to a very different place than where other 'model' educational systems (i.e. Finland, Denmark, etc.) are today? Beyond the foundational cornerstones of democracy, individualism, and pragmatism upon which this nation and its public school system was built [even though it was built for some and not all], it is important to identify the major currents moving forward that prevented curriculum inquiry and school leadership from moving beyond their existing professional silos. Therefore, to better understand the USA context in the present, it is important to consider the rise of neoliberalism during the last quarter century, in particular how it stands in opposition to the conception of Didaktik in northern Europe.

Recent history demonstrates that the rise of neoliberalism marks an ascension to power that has institutionalized governance structures and policies including 
privatization, fiscal austerity, tax reform, deregulation, and free trade. This ideology and its accompanying policies have been embedded by governments on every continent, most notably in Chile under Augusto Pinchot, in the USA under Ronald Reagan, and in Great Britain under Margaret Thatcher. While the effects are worldwide, they have been most strongly felt in the United States in terms of their impact on public education moving further away from the ideals embedded in Didaktik.

Essentially, we see the way forward through a struggle in which the individual "fully enters into reality, so knowing it better, he or she can radically transform it" (Freire 2000, p. 39). We affirm that curriculum inquiry and educational leadership go hand in hand (Reyes-Guerra and Bogotch 2012). Pinar (2004) makes the argument that "As a distinct disciplinary field (rather than a subfield of a single academic discipline such as educational psychology or the sociology of education), curriculum studies may be the only academic discipline within the broad field of education" (p. 2). We believe that school leadership is also an academic discipline within the field because not only does it have an interdisciplinary structure, but it requires the understanding, knowledge, and critique of all the fields in education and society. What is important is the understanding that in northern European circles, Didaktik is still the strong and dominant approach to the foundation of teaching and learning, whereas school leadership and curriculum studies have been slowly neutralized and moved from "scholars and intellectuals to technicians in service to the state" (Pinar 2004 , p. 2). That is, school leaders were converted to managers unable to lead complicated conversations, and curriculum theorists were converted into curriculum designers allowed only to produce materials aligned to the dominant narrative.

Didaktik as a northern European tradition of thinking and studying teaching and learning is unfamiliar to most USA educators today. As Autio (2014) and Seel (1999) pointed out, Didaktik is based on the broader concept of Bildung, "the individual's competence to be able to lead public life: to participate in a knowledgeable way in cultural activities, public affairs, and politics, and to critique - ideally to reconstruct - society by transforming one's self through continuous study and different, idiosyncratic, activities" (Autio 2014, p. 18). Importantly, Didaktik is centered on four elements: moral, cognitive, aesthetic, and practical elements. Didaktik "[m]akes education educative in the real sense of the term: other elements are weighed by the moral and judgmental faculties of the teachers and students alike" (Autio 2014, p. 18). These elements are clearly central to the conceptualization of curriculum and school leadership disciplines, and necessary in building a framework to move the USA forward. Ironically, we will document historical eras, primarily within pragmatic and progressive periods in USA history when curriculum studies and school leadership have come close to a convergence with Didaktik in terms of process and purposes.

However, even when the processes and the purposes in this converging positionality of public education have occurred, it was, is, and will continue to be, as a uniquely "American" phenomenon. The Progressive Movement of the early 1900s marked the stance taken by John Dewey and others (e.g., Boyd Bode) as an educational bridge between "self realization and democratization" (Pinar 2004, p. 17). Therefore, it is this unique American Exceptionality - a term not without 
controversy - which guides our developmental framework by which we embrace the evolution of the social ideals surrounding multiculturalism, democracy and social justice. As a developmental framework in which we document transitions from stratification to homogenization to transformation and to social justice, our task has remained hopeful in spite of recent history and the rise of neoliberalism. We still believe the future is one of a progressive and pragmatic dialogue of mutual respect and interactions among equals, curriculum and leadership.

Nevertheless, dialogue is ever more problematic, as it has to navigate multiple obstacles of temporal policies and politics. Our two fields not only come together and separate contingently, but also are separated from constituents - i.e., practitioners within public education. We have professors of curriculum, professors of school leadership, teacher educators, public school teachers, and public school administrators, each operating independently within their distinct spheres of influence. As if these five constituencies were not complicated enough, there are within each group ideological divides, those who seek to maintain old values and norms (e.g., stratification and homogenization) and those who take a counterview (transformation), or critical perspective (social justice), asking different disciplinary questions. For example, Jerome Bruner (1960/2004) asked his two seminal questions: "What shall we teach and to what end?" (p. 1). Critical educators, such as Geneva Gay, James Bank, Joel Spring, Gloria Ladson-Billings and Michael Apple among others have asked why a curriculum is being developed (e.g. either for the perpetuation of an inequitable status quo; for transformation of the system); "Whose knowledge do we teach?" and "Who benefits from the curriculum?" In the USA, there have always been political struggles over who is included and excluded from public education. It is a perpetual motif in public education in the USA.

\section{Understanding USA Uniqueness: The USA Philosophy and Culture of Pragmatism}

Johann Gottfried Herder and Johann Gottlieb Fichte made strong arguments for the uniqueness of the language, traditions, and culture of a people as a whole that defines the limitations of the political state in dealing with the people that are its subjects or participants. There are strong debates by post-nationalists about US American exceptionalism, yet if there is one strong theme throughout USA history, it is the pragmatism found within the national culture. Pragmatism fits nicely into the "unfinished agenda" in which all USA ideas are debated and then re-interpreted to see which ones matter most in given situations. In William James' (1907/1963) own words, Pragmatism is a mediator/reconciler ... It " unstiffens' our theories" (p. 38, p. 71). "The world is full of partial stories that run parallel to one another, beginning and ending at odd times" (p. 64). It is by understanding pragmatism that we see how the meaning of the "totality of experiences" - a popular notion of curriculum - moved from being a Platonic Idea or Hegelian Consciousness to ongoing 
debates on what it means to be tolerant of queer ideas, on how important it is to listen, and why we need to reflect on alternative ideas of what might be true (Lippmann 1910, pp. 800-801). Pragmatism, according to Henry Steele Commager (1950), "was wonderfully adapted to the temperament of the average America" (p. 97). It translated abstractions into ideas comprehended by ordinary minds. The philosophy embodied a populist message.

William James argued that the disciplines of modern, academic psychology, traditional philosophy and the "science" of education were confusing to practitioners of education, deliberately, using a mystifying language of abstract ideas. His message instead (see his Talks to Teachers, 1899) was one of professional self-development.

You [the audience of teachers] make a great, a very great mistake, if you think that psychology, being the science of the minds' laws, is something from which you can deduce definite programs and schemes and methods of instruction for immediate school-room use. Psychology is a science, and teaching is an art; and sciences never generate arts directly out of themselves" (Psychology and the Teaching Art, Chapter 1 http://www.uky.edu/ eushe2/ Pajares/tt1.html)

James sought to "invent" a practical definition of how ordinary people can understand the meaning of truth or the meaning of any philosophical proposition; that is, he argued that truth comes down to particular consequences based on present and future experiences. There can be no meaningful difference in one's point of view unless it makes a real difference in concrete fact. Pragmatism was James' attempt to accommodate Idealists and pluralists by allowing for the co-existence of opposite points of view when their co-existence did not have any material consequences. It was a criterion for being tolerant, so necessary for any democratic society. By accounting for opposing views, he thought he had reconciled abstract philosophical debates as inconsequential to people's lives. "The true line of philosophic progress lies, in short, it seems to me, not so much through Kant as round him to the point where now we stand" (1907, p. 269)

Locke, Hume, Berkeley, Kant, Hegel, have all been utterly sterile, so far as shedding any light on the details of nature goes, and I can think of no invention or discovery that can be directly traced to anything in their peculiar thought, for neither with Berkeley's tar-water nor with Kant's nebular hypothesis had their respective philosophic tenets anything to do. The satisfactions they yield to their disciples are intellectual, not practical; (p. 83)

Thus, it was left to critical educational thinkers to bring curriculum and leadership to practitioners by engaging them in their lived realities (Boske and Osanloo 2015). This engagement is democratic at its core as it communicates with educators, not 'on behalf of' or 'to' or 'for'. Prepositions in language matter, for research and relationship building. But this in itself will not make any significant difference unless we actively listen to and learn from other educators, communities, and most of all, our students. The learning, listening and acting becomes the praxis or dialogue for our proposed framework. The primacy of practice purposes, processes, and outcomes are all contextual, thus requiring educators to continuously assess the consequences of leadership actions in terms of social justice outcomes (Ayers 2009; 
Bogotch 2002, 2008, 2014). Through James' public lectures to teachers, the meaning of education as negotiation and progressively moves from academics and social change.

As professors and researchers, it is one thing for us to diagnose the problems carefully and systematically and cautiously offer advice. But as educators, our responsibilities lie in our actions, in this case figuring out the next steps to a productive cross-disciplinary dialogue. But before we begin, we will next give a brief USA history to illustrate the twists and turns which have characterized our past relationships.

\section{Re-examining USA Histories as an Unfinished Agenda}

Because the forum for our ideas is international, we will follow an historical chronology so that readers familiar and unfamiliar with the uniqueness of the USA can follow the various twists and turns, continuities and discontinuities reflected in our history. Our illustrations in this narrative will unfortunately omit key personalities, facts, and events that some readers would have liked to learn more about. By necessity, our choices are arbitrary; that is a compromise all educational researchers face. More problematic is that historical figures do not always stand up well in today's light.

Two historical facts dominate any narrative of the USA context: first, we are a relatively young nation, and secondly, we are culturally diverse. As a young nation, the USA is and should continue to be an experiment in democracy, with principles of leadership based on checks and balances (what we call accountability) and the separation of powers (our national distrust of authoritarianism). This has been interpreted in many different pragmatic and progressive ways depending on which era from the 1600 s to the present is being highlighted. The Pulitzer Prize winning historian, Joseph Ellis (2007) refers to it as our history as an "unfinished agenda;" the "people's historian" Howard Zinn (1980/1988) called it the "possibilities of surprise (p. 435);"'and, the noted educational historian David Tyack (1974) saw history as a veritable kaleidoscope of competing interests.

In more practical terms, our history is a struggle between orthodoxy and tradition and modern day practices in all aspects of life. As E. J. Dionne (2012) puts it, "We are a nation of individualists who care passionately about community. We are a nation of communitarians who care passionately about individual freedom" (p. 5). We are a nation of culturally diverse peoples, even when the USA Constitution excluded Indians (Native Peoples) from citizenship (rectified in 1924), and for tax purposes and federal representation reduced Negro slaves to the fraction $3 / 5$ th ' $\mathrm{s}$ in terms of counting the population. Some of the noted architects of our republican form of government, such as Thomas Jefferson, were slave holders which speaks to the ongoing contradictions and tensions created by diversity. Nevertheless, as we will make clear in this chapter, USA public education was designed specifically and 
progressively for the "common man" (sic) as the great equalizer in society as essential to the great experiment in democracy.

Public Education Beginnings The origins of public schools was that they all functioned locally and autonomously for the first century and a half. When the church or orthodox educators controlled knowledge, then teaching the readings and moral lesson of the Bible was a complete answer to Bruner's (1960/1963) two questions: "What shall we teach and to what end?" (p. 1). Primary school students would not only be able to sing), but also have a sense of salvation, either in work, family or in an eternal afterlife. Replacing the Bible with secular readings, made spelling, literacy and calculating numbers not only basic skills, but depending on how many years of education a person received, provided access to secondary, colleges, and universities and a professional life - often a life inside the clergy. In rural settings, the curriculum was delivered by a single teacher in the proverbial one-room school house filled with a community's youth. In many instances, historical and contemporary, the curriculum was prepared outside the school setting and delivered, well or poorly by trained and untrained teachers.

One of the earliest secular - and urban - curriculums was set forth by Benjamin Franklin who synthesized many Western European ideas. In his Pamphlet.titled Proposals Relating to the Education of Youth in Pensilvania Philadelphia, (1749), he listed classical subjects and the reasons for their inclusion in the curriculum. The subjects were divided into two categories: "everything that is useful" and everything that is ornamental." Thus in this very early configuration of curriculum, we have both aesthetic and public ends of education.

Throughout the Pamplet are exhortations in defense of the term "public:"

- "Publick Disputes warm the Imagination, whet the Industry, and strengthen the natural Abilities;" "impressions of the Beauty and Usefulness of Virtue of all Kinds,

- Publick Spirt;" and, "the Necessity of a [CHRISTIAN]

- Publick Religion” (i.e., character education).

Yet, as an independent nation, circa 1776, and especially under the first governance structure, the Articles of Confederation, each of the original thirteen colonies maintained their autonomy, such that each printed its own currency, made its own domestic and foreign policies, each collected taxes, all based on own local, private interests. There was no central authority to coordinate both the business of America, the protection of America or the rights of citizens or establish a public identity (as Franklin's curriculum advocated) or a public good. But what was truly remarkable was that the very same group of well-educated men, landowners, who had conceived of the Articles of Confederation, understood that a new and different governance system was needed. The arguments were made in a series of New York Times essays under the title The Federalist Papers. The USA Constitution set forth a new direction based on the principles of minority rights, "checks and balances" and the "separation of powers," with central authorities focused on the rights of all citizens alongside local decision-making with respect to community and educational needs. 
What is most relevant to us here is the idea that when curriculum is transmitted rather than developed, the "what" or content has been determined externally, apart from the community or apart from the students' abilities and interests. When leadership and curriculum have worked in tandem to improve students' lives and uplift their communities, the first leadership decision is to create the conditions for engaging in curriculum inquiry in order to learn the values, beliefs, and customs of the community. When this leadership step has happened, the school becomes a part of a community with parental and community support. Unfortunately, educational history is replete with periodic examples of external authorities deciding from afar what all USA communities' need. The idea of school and community is as old as the nation. And yet, it remains problematic in terms of both leadership and curriculum inquiry and its development. But in order to understand the many examples of school and community throughout USA history and contemporary times, it is necessary to see how radical and dramatic governmental change happens.

\section{The Emergence of Public Education}

It was Horace Mann who insisted that public education be democratic in structure and practices. His design of normal schools in Massachusetts in the 1830s-1840sff were designed not to change the arduously difficult lives of immigrant parents, but rather through schooling to change their children who could rise up out of drudgery and poverty in one generation. Horace Mann himself personified the effective integration of leadership and curriculum. The design of normal schools was that teachers were educated in the mornings and then they taught students in the afternoon. And when it came to immigrants of Irish, Italian, Polish, and Jewish descents, his single generation goal became almost a two century mantra of those who enrolled in public schools. That said, for other non-white immigrant groups, they have never fared as well inside either separate but equal or integrated public schools (Greer 1972, Perlman 1988).

Although Mann himself championed integration and the end of slavery, it was not until the passage of the 13th, 14th and 15th Amendments to the USA Constitution after the bloody Civil War, in the 1860s, that a new transformational era in USA history was initiated by President Abraham Lincoln. Lincoln chose war in order to keep the nation whole and not let economic or political differences destroy the country's system of government. The above amendments abolished and prohibited slavery; conferred citizenship on persons born or naturalized in the US; prohibited denying voting right to citizens based on race, color and previous servitude.

By the turn of the twentieth century, public schools faced new challenges of immigration and poverty caused by urbanization, parental neglect and truancy. Schools were called upon to provide a new progressive curriculum and philosophy (i.e., Dewey). And thus were born schools in conjunction with settlement houses (Addams 1910/1961; Berger 1956/1980, Patri 1917). Quoting from Patri: 
We looked upon the settlement as a moving living force whose idea was one of service and not of power. Free from tradition, we felt that it would be the neighborhood social experimentation station, finding out, working out, and then beginning again, never stopping long enough to standardize. (p.134)

The settlement houses addressed economic issues while also instilling a meaning for democratic citizenship. The reform, like the origins of government were "experimental rather than permanent (Berger 1956/1980, p. 2) although the principles underlying this and many other educational reforms were meant to be permanently instilled in society. Even during the two World Wars and the Great Depression, public schools sought to become sanctuaries with "playgrounds and school gardens, shower baths and swimming tanks, manual training and domestic science, branches of the public library, vocation and evening schools, schools for deaf and blind children, auditoriums for use by pupils with free lecture courses and concerts, and in general the opening of schools after hours as neighborhood centers" (p. 90). For progressives, education was a social institution to promote community well-being and democracy (p. 105).

\section{An Historical Convergence}

The Progressive Movement in USA history had multiple philosophers, including James whom we have already presented. However, the premier philosopher in progressive education was John Dewey, who, inspired by James, then introduced instrumentalism as a philosophy and called for radical reform of curriculum and teaching. Always tempered by his primary ethical value of democracy, he countered the traditional approach to education with progressive education. His philosophy opened, on multiple levels, the doors to a strong convergence of leadership and curriculum that we are advocating. Dewey's emphasis on democracy as a way to protect popular interests, democracy as an expression of individuality, and democracy as a method of social inquiry were foundational as litmus tests of progressive education.

One of the most vivid examples of curriculum and leadership working in concert to build community was the planned community of Arthurdale, 1934-1936, the first subsidized project of the Roosevelt administration's New Deal. It was an experiment to educate the displaced coal mining families of West Virginia:

It is proposed that, just as the organization of this community represents an experiment seeking to discover means of needed adjustment in our social and economic life, likewise let this be a new school, providing for its citizens of all ages richer and more adequate educational opportunities (Stack 2004, p. 188).

The school principal, Elsie Clapp's leadership began with two non-negotiable demands: one, that she was able to bring her experienced staff with her to the new school community; and, two, was that she would not open the school until she and her teachers had acclimated and assimilated themselves into the community so that 
the curriculum would be based on the real needs of the students. The formerly city educators were now studying "farming, homesteading, village games" [because] "understanding cultural heritage was a central component of self-realization" (p. 196). The structure was to hold classes day and night for everyone in Arthurdalefrom ages 2 to 72 . Teachers became active members of the community, volunteering as firefighters and building greenhouses, recreation buildings, libraries, cafeteria and kitchens, home economics, a doctor's office, a bank and bookstore (p. 200).

But as history unfolded neither the settlement houses nor the Arthurdale experiments continued. What happened? For one thing, Dewey's progressive ideas were never embraced by traditionally trained educators whether in curriculum or leadership. As Dewey repeatedly noted, progressive education was too difficult conceptually for teachers and administrators who did not receive the kind of rigorous education advocated by Franklin, Jefferson or Mann. Instead teacher educators have participated in what William Doll (1993) referred to as the "methodologization" of curriculum. Progressivism required that the students' knowledge, interests and abilities inform the teacher who listens and learns from them, co-constructing the sequencing and pace of instruction within all subjects being taught. In contemporary terms, progressive practices have led to a more critical pedagogical approach which holds that "what works" for disadvantaged students, often students from minority cultures and races" actually works for all students, while culturally insensitive curriculum, that is, colorblind and objective practices, do not work for minoritized groups of students (Grant and Sleeter 2011). Moving from constructivism to critical constructivism has become one of today's curricular challenges inside the academy.

Resistance to progressive ideas had deeper roots in the USA society than just pedagogies and methods. And for this reason, Dewey's philosophy of education was grounded in his battle to combat the anti-intellectual state of affairs within education. He wrote essays on democratic relationships, educative habits and experiences, artistic appreciation, and engaging in the public's problems - all attempts to broadened progressive educational ideas beyond schooling.

\section{Wrong Turns: From Historical Injustices to the Neoliberal Assault on Public}

Education Throughout USA history, political, cultural and social ideals and ideologies have competed for power. It is always within a larger socio-cultural and political environment that we must see public education. But when education goes wrong, it goes wrong when curriculum and leadership come together to cause cultural and psychological damage to students and/or when the disparate impact of practices and policies keep minoritized groups from participating in the opportunities afforded to others in society.

The impact of scientific management imbued with the valuing of social efficiency has raised significant concerns for multiculturalism, democracy and social justice (Kliebard 2004). Bobbitt (1918/2013) made the case for the "technique of curriculum making along scientific lines" (p. 12) that prioritized the efficient use of resources. According to Flinders and Thornton (2013), 'For Bobbitt, 'scientific' suggested a systematic series of procedures, carried out by curriculum professionals, 
prior to implementation in a school district" (p. 4). Teachers and their supervisors were recipients of this externally derived curriculum. This methodolization of curriculum emphasized the "how to" of curriculum design, highlighting the interconnections among objectives, content, instruction and assessment, as exemplified by the work of Ralph Tyler (1949). This short text inspired scores of curriculum specialists in decades of discussions and debates on the development of objectives and varied models and frameworks for curriculum design. Although Tyler called for the purposes of curriculum grounded in broader concerns, preoccupation with efficient development and delivery became the focus of curriculum specialists. As Klein (2003) observed, instructional strategies such as "behavioral objectives, time on task, sequential learning, positive reinforcement, direct instruction, achievement testing, mastery in skills and content, and teacher accountability" (p. 21) became more valued as the domain of school-based educators.

The ability to "efficiently" deliver curriculum, rather than to question it, provided fertile ground for the proliferation of scholarship on curriculum design methodologies as well as for the growth of externally derived standardized curriculum. Teacher education programs honed the skills for practitioners' instructional development separate from the curriculum. Ensuring that the pre-determined learning outcomes are met and measured is a priority. Depending on the context teachers may have the license to achieve these outcomes in creative and personalized ways; in other contexts supervisors expect teachers to instruct in narrow and scripted ways. The convergence between curriculum and leadership within this paradigm is as seamless as it is sublime with the expression "aligned with fidelity" rolling off the tongues of today's teachers and principals as if their bonding over such reforms will in fact close the achievement gap and turnaround schools. We express this with as much sarcasm as we can muster because it reveals a larger political and economic agenda afoot.

To wit, the bogeyman that has extended the historical injustices into the present is often referred to as neoliberalism. According to Pinar (2004), it is complicit in schools and universities becoming a "skill-and-knowledge factory (or corporation); the education professoriate is reduced to supervisory personnel" (p. 3). Educators at all levels have lost the moral consideration so central to Bildung, Didaktik, and to Pinar's complicated conversation of currere in curriculum inquiry. There is even a bifurcation at the university level: at some institutions, students, teachers, and professors are not engaged in complicated conversations at any or all levels, while at others attempts are made, but they are isolated within the ivied walls of the institution and end when the teachers and leaders enter the school.

It must be noted that the overarching principle of neoliberalism is that all things have value because all things are commodities. Citizens are no longer citizens, as they are now global investors who can invest their capital for profit across the world, employers who look for the cheapest workers on the planet to produce goods, and consumers who purchase the production that then returns investment on the capital put out by the investors. There is no common good but that which is produced by the market forces of competition and the profit obtained by individual greed which then, somehow, allows the world to be a better place for all by meeting the 
self-indulgences of the consumers of these commodities. As Harvey (2005/2010) pointed out, the system works as long as there is a $3 \%$ average return on investment, but that 'system' is 'working' only for the investor and for those who are a part of the elite who manage those investments, be they corporate CEOs, stockbrokers, or those who have discovered a market where their labor is sufficiently valued to allow an income that places them in the investor class.

In this neoliberal setting, privatization, fiscal austerity, globalization, and free trade (competition) must become the focus of the government and policy in order to bring profit to the capitalists involved and cheaper commodities to the consumer. For public education, applying these principles results in two different trends. The first allows for education to be converted into a commodity, where students and parents are consumers. Privatization has meant turning public schools into independent, privately run schools or charter schools, whose purpose is to turn a profit as measured in the production of test scores or as measured in the efficiency of the private management organizations running and profiting from these schools. Education therefore is not about currere, it's about maximizing the 'profit' measures. Fiscal austerity, a means of getting more productivity out of less workers, has meant that schools and educational programs are given less resources (tax dollars) for funding in order to force greater productivity - consideration is not given to anything but those endeavors that will produce rising test scores, so moral, cognitive, aesthetic, and practical elements are ignored.

The second and more subtle trend is that by turning education into a commodity, the profession itself must change into a commodity producer and educators simply the corporate workers who develop and produce that commodity. And that commodity, learning, has to be packaged and delivered in uniform ways to allow for both an opening of the market and competition. This has meant that instead of curriculum or leadership becoming more contextual, more democratic and therefore by definition more focused on social justice and multiculturalism, these two disciplines have become commodified, specialized, and even further silo-ed by the policies enacted. Accountability, a word that plays on the sensibility of the general public, is actually a way for corporations to sell software, data tools, and testing materials to the over 13,500 school districts in the USA. But be clear, the USA is too small a market for the largest educational corporation Pearson Education, which is advancing globally and digitally into emerging markets, and taking full advantage of the newly created competitive market based on international standardized testing (e.g., PISA, TIMMS). Neither context nor currere exist. As Pinar (2004) states, "[by] tying the curriculum to student performance on test scores, teachers are forced to abandon the intellectual freedom to choose what they teach, how they teach, and how they assess student learning" (p. 164). 


\section{The Way Forward: A Tentative USA Framework}

Our reflection on USA history reveals the ongoing intergenerational struggles to realize the ideals of multiculturalism, democracy and social justice across curriculum theory and leadership. Just as the wrong turn was taken with respect to the infamous Native American Boarding schools, which turned out to be sites of cruel cultural genocide and militarism, and just as the enlightened turns of progressive and democratic community education were made within settlement schools, the two sides of the USA coin demonstrate that it is only when curriculum and leadership were inclusive of diverse participants coming together democratically and for socially just ends, that the dialogue was pragmatic and progressive, necessary and contingent.

The new conversation to be forged between leadership and curriculum is in our view best grounded in Freire's (2000) notion of dialogue between interlocutors engaged in a mutual struggle against injustice. In a way, dialogue serves both as metaphor as well as a process for re-framing the relationship between curriculum and leadership educators; it also signifies the desired relationship between curriculum/leadership professors and public schools. For Freire, dialogue is a transformative and humanizing process of mutual reflection and action, forged in love, humility, faith, hope and critical thinking, with a view to engaging in collective action in solidarity with oppressed groups.

Many public schools in the USA, particularly those that serve racially and economically marginalized students, offer appropriate yet urgent spaces within which such dialogue could occur. Currere holds, for us, the notion of curriculum as personal enactment - our lives as curriculum, as well as Freire's perspective signified by the dialogue: we make the road by walking. It is a notion of Freirean praxis forged through action and reflection in the dialogic encounter. The formal curriculum or conceptualization of the curriculum as a plan for instruction is only a limited facet of the definition of curriculum central to our discussion.

The context of curriculum will determine the nature and trajectory of the dialogue required between curriculum and leadership. Within the USA, the preservation of privilege has given rise to social efficiency undergirding the relationship between curriculum and leadership. The use of standardized curriculum in what has been variously referred to as the canon, a master-narrative, reflecting a culturally arbitrary (Bourdieu and Passaron 1977/1990) perspective, where assimilation of diversity towards a homogenized perspective was valued necessitates curriculum leadership that prioritizes monitoring, enforcement, and evaluation based on a priori, externally imposed standards. It is within this state of affairs today in contemporary USA that a significant amount of public funds are expended on the development of standardized tests, their administration and assessment, by private companies (e.g., Pearson), despite widespread criticisms by prominent USA educators such as Dianne Ravitch (2014) and David Berliner (2011).

Our path forward is necessarily informed by our critical reflection on our past. Our history reveals varied potentiality for the desired dialogue between our fields. 
On the one hand, we have spaces where limited dialogue in the context of common conceptualizations has been beneficial to maintaining an inequitable status quo; on the other hand, we recognize that curriculum as a complex, community based undertaking for social justice necessitates dialogue as counter-hegemonic praxis. Movement towards this latter notion of dialogue, is likely to require multiple steps. Gay (2001) wisely noted in the context of multiculturalism that an institution's development and readiness was a factor in the level of transformation to be expected. We reckon the same is true of transformative dialogue. History demonstrates that the relationship between curriculum and leadership is mediated by the conceptualization of curriculum adopted within specific community contexts. To this end, we identify four conceptualizations of curriculum that have been effected in the USA and explore the varied relationship between curriculum and leadership that each portends. For each, we look through the lens of multiculturalism, democracy, and social justice to examine the predicated outcomes.

Curriculum for Stratification Assimilationist and racial stratification policies have been endemic to US curricular practices in public education. The policies towards Native Americans, African Americans and subsequently towards generations of immigrants have included explicit plans for segmented assimilation (Portes et al. 2005; Portes and Zhou 1999). We see, on the one hand, the efforts to rid students of their native tongue, cultural values, in efforts to "Americanize" them; on the other, the denial of education either through explicit laws, or their lack of enforcement, ensured social control of different groups. (Spring 2013) quotes the advocacy of discrimination towards students of Mexican descent by a farmer, a school superintendent and a principal: "Educating the Mexicans is educating them away from the job, away from the dirt" ... It is up to the white population to keep the Mexican on his knees in an onion patch; this does not mix well with education .... Never try to enforce compulsory attendance laws with Mexicans. The banks and the company will swear that the labor is needed" (p. 95). Such overt racism also forced pragmatic educators, such as Booker T. Washington to press for "education before equality" in an effort to make the best of stratification policies.

Clearly, curriculum for stratification is a violation of any current conception of social justice. In fact, stratification is the opposite of inclusion, and inclusive schools as an overarching conceptualization "provides effective strategies school leaders operating from a social justice framework can implement to create more inclusive schools for all students" (Esposito and Normore 2015). Stratification parallels the curriculum of the status quo within the USA from which we wish to deviate. Alarming disparities in academic achievement due to the historic lack of resources and deliberate withholding of institutional support (Ladson Billings 2006) are further exacerbated through standardized testing regimes that link students' test scores to school funding and teacher salaries, reduce curriculum and leadership to a focus on test preparation through drills and instructional routines grounded in factory-like efficiencies. These contribute to the increasing racial re-segregation of public schools (Kozol 2005). Despite widespread scholarly condemnation of these practices, they remain well-entrenched within the public education system, supported in 
large measure by corporate entities who benefit financially from the increased testing, monitoring and data management that now characterize public education.

The widespread acceptance of this curriculum signifies a separate-but-equal compliance by curriculum and leadership practitioners in the perpetuation of narrowed, decontextualized and largely prescriptive curriculum. Educator preparation programs, swayed by test-based accountability and funding formulae, abandon any semblance of the principles linked to the notion of Didaktik to teach compliance with state standards for practitioners whose primary role is to uphold this system. The intensification of workload that comes with such de-professionalizing practices (Apple 1986) typically precludes opportunity for collaboration at any level, except for ensuring that standards are met across the system. Local control, democratic values that include social inquiry (Dewey 1916) are all violated in this form of curriculum.

Curriculum for Homogenization Curriculum for homogenization also draws on notions of standardized curriculum but with a distorted commitment to social justice and democracy that emerges from the concern about equal outcomes among different groups. Although framed also as the potential for access to knowledge variously described as cultural capital (Bourdieu 1986), cultural literacy (Hirsch 1996) and/or the culture of power (Delpit 1988), it often comes at the price of home language, cultural identity and curricular relevance. The curricular focus here typically privileges pre-determined content with emphasis on instructional methodology. Multicultural criticisms draw attention to largely monocultural (Banks 2001) and biased (Loewen 2008; Sadker and Sadker 2000) content that risks intellectual enslavement or colonization. As Woodson (1933) so eloquently reminded us, "If you can control a man's thinking, you do not have to worry about his action" (p. 84).

May and Sleeter (2010) report that standardization of curriculum towards homogeneity increased in the rhetoric against multiculturalism post 9/11; furthermore framing everyone as equal citizens detracted from the unequal power relationships that existed among groups. Goals of homogenization inevitably include deficit orientations where their "differences" are problems to be overcome, rather than assets to be built on. Thus, within the classroom, homogenization occurs through teachers' instructional strategies. At the level of the school, principals make professional development, budget, instructional support and teacher retention decisions that minimize the "gap," with little opportunity to question the received curriculum nor the policies that are foundational to such inequities. In the context of educator preparation programs, a curriculum as science perspective emphasizes lesson plan development aligned with state and local standards in teacher preparation (in plans that typically foreground procedures rather than concepts), scientific/rational curriculum design opportunities in the preparation of curriculum specialists and a managerial/administrative/supervisory focus in principal preparation.

Curriculum for Individual Transformation This conceptualization of curriculum more clearly identifies the potential for productive intersections between leadership and curriculum as the purposes and the intersections between the formal and the informal reveal a distinct departure from the previous two conceptualizations. 
It draws on a more polyphonic perspective of curriculum, rooted predominantly in the holistic development of the student as a human being. It integrates the multiple sources of curriculum to achieve a broader set of learning outcomes that extend beyond subject matter mastery per se, but where such knowledge becomes the basis of intellectual, social and civic development. Within this perspective, curriculum is broad-based, dynamic and multidisciplinary, drawing on the values of aesthetics as much as on science, social science, humanities, and languages and characterized by inquiry-based approaches to instruction. In this conceptualization, curriculum emerges as an art, not a science; it is a verb (Padgham 1988) not a noun. It is local and context-based, emerging from the specific needs and interests of the students, the community and their educators. Here tests and accountability do matter, but they do not drive the curriculum.

Historical manifestations of such an approach are evident in the work of Montessori (2013), whose pursuit of child study railed against the narrow conceptions of science noting, "The school must permit the free, natural manifestations of the child if in the school scientific pedagogy is to be born" (p. 25; italics in original). Dewey, whose prolific scholarship offered the balance between and among prescribed curriculum, student-centered learning and social responsibility in a democracy. Greene's $(1978,2000)$ exhortations for creativity and the imagination in the development of the consciousness of the individual, Eisner's (2002, 2003, 2005) challenge of the scientific notions of curriculum and pre-determined objectives, together with Robinson's (2006) observation that schools were both anachronistic and stifled growth and creativity support this conceptualization of curriculum, in strong criticism of the rational/scientific view of curriculum.

This democratization of curriculum demands vastly different responsibilities of teachers and leaders, including a shift in the responsibility of curriculum development. In the absence of the pre-packaged curriculum faithfully transmitted to students, school-based educators become responsible for facilitating the development of curriculum; what is worth knowing emerges from a process of collaborative investigation; lesson planning is conceptual rather than a technology. Outcomes such as students' self-actualization, identity development, cross-cultural competence and civic consciousness gain importance as knowledge is understood as dynamic and co-constructed. Inclusivity in this process will require comfort with divergent thinking and communication that fosters consensus building.

Consequently, how the fields of curriculum and leadership prepare their students for this reality becomes crucial. If curriculum studies programs adopt a curriculum as science perspective, their graduates will be ill-equipped for contexts requiring a more dynamic approach. Similarly, if educational leadership programs are solely focused on scientific approaches to ensure mastery of pre-determined and unquestioned curriculum, teachers prepared as curriculum inquirers will be stifled under such leadership. It thus becomes crucial for academics in these two fields to work closely as they prepare teachers, curriculum developers and leaders for conjoint practice in their communities. While such collaboration is central to the dialogue proposed at the next level of this typology, what is different here is a matter of focus. The focus on the individual lays the groundwork for transformative leadership 
(Shields 2014) and transformational curriculum (Banks 2001), each endorsing the value of divergent perspectives in a dynamic view of leadership and curricular implementation. This lays the requisite groundwork for transforming entire institutional structures. This is not a challenge to be undertaken by a single entity; it will require broad-based coalition building.

Curriculum for Social Justice Contemporary educational policy and practice in the USA, despite its rhetoric, has fallen prey to a technocratic managerial system, obsessed by measurement but with little meaningful learning going on in the 8 months leading up to the annual test (Rose 2011). Of particular concern is the impact of the current system on historically under-served students in the USA. As Rose (2011) notes:

This concern about the nature of a school's response to high-stakes pressure is especially pertinent for those students at the center of reform: poor children, immigrants, and racial and ethnic minority students. You can prep kids for a standardized test, get a bump in scores, yet not be providing a very good education. The end result is the replication of a troubling pattern in American schooling: poor kids get an education of skills and routine, a lower-tier education, while students in more affluent districts get a robust course of study. (pp. 34-35)

The ongoing struggle, especially in the current context of neoliberal politics that have gripped public education at the primary, secondary and tertiary levels, will require intentional coalition building between and among diverse constituents if a vision for social justice education is to be realized. Shields' (2014) call for transformative leadership for social justice education focuses on "the very nature of the school and its relationship with the wider community" (p. 325). This entails transformation in the formal, prescribed curriculum, as well as in its hidden curriculum of policies, practices, values, climate and community relationships. Apple and Beane (1995) observed similarly in their study of democratic schools in the USA:

Democratic schools, like democracy itself, do not happen by chance. They result from explicit attempts by educators to put in place arrangements and opportunities.that involve two lines of work: ... to create democratic structures and processes by which life in the school is carried out. The other is to create a curriculum that will give young people democratic experiences. (p. 9)

Curriculum for social justice builds on the legacy and vision of social reconstructionists who called for curriculum to be a catalyst in the transformation of inequitable social structures. It supports what Ladson-Billings (1995) calls culturally relevant pedagogy defined as a humanizing pedagogy of opposition that leads to collective empowerment, students' academic success, cultural competence and critical consciousness that facilitates their ability to question an inequitable status quo. This approach parallels the principles of critical pedagogy, inspired by the work of Freire (2000) and popularized in the USA by critical scholars (e.g. Apple 1986, 2006, 2012; Giroux 2011a, b, 2013; Kincheloe 2008). Critical pedagogy draws attention to the oppressive potentiality of curriculum, where students were treated as passive recipients of knowledge. Instead, Freire called for more emancipatory pedagogy that would facilitate active engagement through dialogue in a mutual process of reflection and action that constituted the praxis by which learners might act 
upon their world to transform it. The cases highlighted by Apple and Beane (1995), the (now banned) Mexican American Studies program of Tucson, AZ, and the Chicago Grassroots Curriculum Taskforce (CGCT) offers a prototype for community-based curriculum development integrating students, their families, community elders and school- and university-based educators to compile a collective knowledge of Chicago's communities (http://grassrootscurriculum.org/ about-us/).

\section{Curriculum Options for Democracy, Multiculturalism, and Social Justice}

As we mentioned earlier, there are four elements of Didaktik that provide a direction for bringing our two USA disciplines of leadership and curriculum together: the moral, cognitive, aesthetic, and practical elements. But the meanings of these terms are derived from history, national contexts and cultural perspectives. Thus the curriculum options begins with a four by three matrix in which we frame the four elements of Didaktik alongside democracy, multiculturalism, and social justice. Beyond social, political and economic stratification and beyond the "melting pot" metaphor of the Ss. Clearly, the two curriculum conceptualizations that begin to meet the criteria for effecting radical change are the Individual Transformation and Social Justice curricula. This means that curriculum and leadership programs must lead to the development of teachers and leaders who are able to effect needed changes in both individuals and communities.

For many scholar-practitioners who are working in pockets of isolation within the academy, where multicultural, democratic, and social justice concerns have been relegated to marginal status, this becomes an especially difficult challenge. Too few programs in education have made multiculturalism, democracy and social justice integral to their program philosophy in action, rather than merely in rhetoric. Too rarely does this philosophy extend to multiple programs such as its leadership preparation and its curriculum/teacher education. Instead, many programs still focus on the traditional curriculum developed with a certain dysconciousness (King 2000, 2015) of the structures of inequity that shape and are perpetuated by extant curriculum. Furthermore, in the high stakes context of assessment, where - in an egregious mismeasure of quality - educator preparation programs in public institutions will be measured and funded by the test scores of our graduates' students, educator preparation institutions appear more keen to gear their curriculum towards compliance with such policies, rather than interrogating them. 


\section{Conclusions for Complicated Conversations That Must Result in Action}

While in the broadest sense of leadership practices which does not delimit leadership to roles, functions, and structure), curriculum theorists are, in fact, educational leaders in that they interact with others. Our framework identifies these others not just in terms of the socio-cultural situation, historical eras, but also the key participants, which includes those held responsible for educational decisions and outcomes. Thus, the focus on the interactions between curriculum and educational leadership.

One of the very few curriculum theorists to have a clear view of these interactions with educational leadership was Alice Miel. In 1961, she delineated five prerequisites for leadership in schools: "(1) a professional atmosphere, (2) a climate of psychological safety with freedom, (3) staff learning opportunities, (4) opportunities for decision making, and (5) opportunities for cooperative evaluation and selfevaluation (p. 229). Following Dewey, Miel asserted that pedagogical content should never be limited to the transmission of already existing ideas, but rather engage with students in activities whereby new ideas emerged and were reconstructed. Thus, curriculum would never be static but always guided by a social construction through trial and error. For Miel, leadership was a matter of balancing safety and challenge, control and release with a freedom "to venture into uncharted territory where instructional material have not yet caught up with events" (p. 252). She called her leadership theory "ordered freedom" a liminal space between the status quo and agency for change - which for both administrators and teachers are a "never-ending challenge" (p. 252).

According to Reyes-Guerra and Bogotch (2012) "the field of curriculum theory and inquiry has been grounded in educational concepts, such as development, growth, discovery, progressivism, democracy, morality, and reconstruction" (p. 138). They stated that "While the formal definition of curriculum found inside catalogues, brochures, and Web pages describe it as what is taught and learned in single classrooms, curriculum [check the wording of this quote], as we learned in our undergraduate teacher-education years, is the totality of experiences - with multiple dimensions, including cognitive, social, political, economic, moral, aesthetic, cultural, and spiritual aspects of life - not just for living today, but also to be transmitted generatively from generation to generation. As such, curriculum inquiry demands that participants have the freedom to be creative and innovative." (p. 141).

It was the unintended consequence that two American pragmatists, William James and John Dewey, who were both trained as scientists, pushed open the door of tolerance, experimentation, and democracy only to witness how dominant groups in society walked through that door to impose their own selfish ideas or to propose a "new" science of psychometrics (e.g., Thorndike) and scientific management (e.g., Taylor, Bobbitt, Courtis) which has for a century now dominated USA education in policies and practices. Pragmatism and progressivism have struggled over the past century in the face of quantitative proofs and statistical methodologies. It is 
up to us to insist on the reconstituting a new pragmatic test: promoting dialogue focused on that which is good and eliminating that which causes psychological and bodily harm.

Dialogue, within the Freirean context arises from the identification (or "naming") of social injustice and is sustained through mutual engagement with the parties affected by the injustice in order to transform the conditions that give rise to it. The given name to that injustice will differ across the globe according to contexts from which opportunities arise. Contexts and opportunities differ nation by nation. In the case of the USA, we recognize that the inequities of contemporary education here are a legacy of the historical, economical, sociopolitical and moral debt owed to specific groups through educational policies and practices explicitly aimed at their annihilation (Grande 2004), stratification (Gonzales 1996) or miseducation (Woodson 1933). Thus it is incumbent on all educators who claim a stake in the equitable education of all students to identify ways that interrupt the current entrenched practices.

This interruption will require conscientization (i.e. critical awareness of the political dynamics that give rise to the unequal distribution of power) at multiple levels. First, is the recognition of the curricular problem itself, its causes, manifestations and results. Second, is the acknowledgement of our own professional culpability in sustaining this untenable curricular reality and our potential, individually and collectively in transforming the conditions that give rise to injustice. Third is our obligation to "wake" others up, - whether they are educators, students, administrators or community members - to the reality that injustices exist, and their own role in its perpetuation. Part of this awakening is to the institutional conditions in which all educators work.

The dialogue we seek, following Freire, must begin in the context of local manifestations of injustice. School-based or community-based injustices become the "laboratories" in which all educators (indeed all stake-holders) learn and work together. In these contexts all are learner-teachers; all are potential leaders (a role that has no connection with title or credentials); all are curriculum developers. In these roles we recognize that curriculum is not merely what we plan that students learn, but also the messages generated intentionally and unintentionally through our leadership actions in the community. Leadership, in the context of the dialogue entails active listening, soliciting the voices of those unheard and facilitating the collective critical consciousness and empowerment for action.

For university educators this engagement serves multiple purposes. It solidifies the recognition that, in much like the interdisciplinary projects undertaken by curriculum artists, the real problems of school and community cut across disciplinary boundaries. Stepping out of academic siloes to work collaboratively translating our theory into practice, provides us opportunity and rationale for moving beyond these boundaries, such as they exist, within the academy. Seeing the need for our collaboration and engagement in the sites of social injustice within our communities, would likely prove catalytic in our work, both separately and together within our own institutions. Separately, we engage in this work in our classes, our writing and 
institutional obligations but now ever mindful of our separate but equal paths in the collective undertaking towards social justice.

Yet none of this will lead towards an educational system that is led and engaged in curriculum inquiry undergirded by democracy, social justice, and multiculturalism if those three values are not embedded in the theoretical learning and practical application of our disciplines. What excuse is there for our disciplines if the educational leaders and teachers that we produce - both those dedicated to scholarship and those dedicated to its application in public schools - have not achieved conscientization and are not practicing to these ends. Moreover, if they are not engaged in questioning, understanding, and practicing these ends, then how will the students they teach be liberated? Clearly, in the USA our students of today have no conception of social justice, multiculturalism, or democracy as we understand them. They are, after all, like the educators that work with them, subsumed in a neoliberal system that rejects those values.

However, as we have discussed, the USA is pragmatic. Through compromise and practical actions our disciplines can effect change. The recognition of persistent injustices in education compels us to publicly ask of our programs, departments, colleagues and leaders about our institutional role in the interruption of or complicity with such policies and practices. When accrediting bodies or state certification regulations continue their historic practice of using education to marginalize diverse communities, or assume that homogenization of difference is a benevolent educational practice, what has been, is, and/or should be the role of professors in curriculum and leadership and how should they be confronted? Preparing future educators to recognize this injustice, and doing so in tandem, where future principals and teachers enter the field 'on the same page' with regard to diversity and injustices is an important step. But working in isolation in our isolating professional and institutional settings proves inefficient when the status quo of public education needs to be challenged.

Critical perspectives of our fields compel us to recognize our own complicity in setting up the conditions by which technocratic and marketizing forces have uprooted the democratizing aspirations of public education. The siloed existence has precluded dialogue as critical praxis within the academy to the extent that colleges of education as well as public universities themselves have fallen prey to neoliberal ideology and the logic of competition, profiteering and measurement. A naïve consciousness, as Freire described it, has engendered institutional complicity within systems and practices that disempower. While the specifics of how such dialogue occurs might be context-dependent, the rationale for it is clear. We must become "wide awake" rather than anaesthetized to the politics of neoliberalism and marketization that has de-professionalized our educators and that threatens the humanizing, democratizing and empowering potentiality of education, and we must become radical in our approaches to address them. 


\section{References}

Addams, J. (1910/1961). Twenty years at hull house. New York: Signet.

Apple, M. W. (1986). Teachers and texts: A political economy of class and gender relations in education. New York: Routledge.

Apple, M. (2006). Understanding and interrupting neoliberalism and neoconservatism in education. Pedagogies: An International Journal, 1(1), 21-26.

Apple, M. (2012). Foreword. In W. H. Watkins (Ed.), The assault on public education: Confronting the politics of corporate school reform (pp. ix-xiv). New York: Teachers College Press.

Apple, M., \& Beane, J. (Eds.). (1995). Democratic schools. Alexandria: ASCD.

Autio, T. (2014). The internationalization of curriculum research. In W. F. Pinar (Ed.), International handbook of curriculum research. Routledge. https://www.routledgehandbooks. com/doi/10.4324/9780203831694.ch1. Accessed on 27 June 2015.

Ayers, W. (2009). Handbook of social justice in education. Abingdon: Routledge.

Banks, J. A. (2001). Approaches to multicultural curriculum reform. In J. A. Banks \& C. M. Banks (Eds.), Multicultural education: Issues and perspectives (4th ed., pp. 225-246). New York: Wiley.

Berger, N. (1956/1980). The settlement, the immigrant and the public school. New York: Arno Press.

Berliner, D. (2011). The manufactured crisis revisited. http://schoolbriefing.com/1967/the-manufactured-crisis-revisited/ retrieved 8/14/2015

Bobbitt, F. (1918/2013). Scientific method in curriculum-making. In D.J. Flinders \& S.J. Thornton (Eds.), The curriculum studies reader (4th edition). (pp. 11-18). New York: Routledge.

Bogotch, I. (2002). Educational leadership and social justice: Practice into theory. Journal of School Leadership, 12, 138-156.

Bogotch, I. (2008). Social Justice as an educational construct. In I. Bogotch, F. Beachum, J. Blount, J. Brooks, \& F. English (Eds.), Radicalizing educational leadership: Dimensions of social justice (pp. 79-112). Rotterdam: Sense Publishers.

Bogotch, I. (2014). Educational theory: The specific case of social justice as an educational leadership construct. In I. Bogotch \& C. Shields (Eds.), International handbook of educational leadership and social (In)justice. Chapter 4. Dordrecht: Springer.

Boske, C., \& Osanloo, A. (2015). Living the work: Promoting social justice and equity work in schools around the world. Bingley: Emerald Group.

Bourdieu, P. (1986). The forms of capital. In J. Richardson (Ed.), Handbook of theory and research for the sociology of education (pp. 241-258). New York: Greenwood. Bordieu (1986) referred to at $\mathrm{p} 13$.

Bourdieu, P., Passaron, J-C. (1977/1990). Please fill in year/page/replace xx in the reference. Reproduction in education, society and culture.Thousand Oaks: Sage Publications.

Bruner, J. S. (1960/2004). The process of education. Boston: Harvard University Press.

Commager, H. S. (1950). The American mind: An interpretation of American thought and character since the 1880s. New Haven: Yale University Press.

Delpit, L. (1988). The silenced dialogue: power and pedagogy in educating other people's children. Harvard Educational Review, 58(3), 280ff.

Dewey, J. (1916). Democracy and education. New York: Macmillan Co.

Dionne, E. J. (2012). Our divided political heart: The battle for the American idea in an age of discontent. New York: Bloomsbury.

Doll, W. E. (1993). A post-modern perspective on curriculum. New York: Teachers College Press.

Eisner, E. (2002). What can education learn from the arts about the practice of education? John Dewey lecture the encyclopedia of informal education, www.infed.org/biblio/eisner_arts_and_ the_practice_or_education.htm

Eisner, E. (2003). What does it mean to say that a school is doing well? In A. C. Ornstein, BeharHoresnstein, \& E. F. Pajak (Eds.), Contemporary issues in curriculum (3rd ed., pp. 239-247). Boston: Allyn \& Bacon. 
Eisner, E. (2005). Re-imagining schools: The selected works of Elliot W. Eisner. World Library of Educationalists Series. New York: Routledge.

Ellis, J. (2007). American creation. New York: Vintage Books.

Esposito, \& Normore (2015) Race ethnicity and evolution of critically compassionate intellectualism.

Flinders, D. J., \& Thornson, S. J. (2013). The curriculum studies reader (4th ed.). New York: Routledge.

Franklin, B. (1749). Proposals relating to the education of youth in Pennsylvania. Philadelphia: University of Philadelphia.

Freire, P. (2000). Pedagogy of the oppressed (30th ed.). New York: Continuum.

Gay, G. (2001). A multicultural school curriculum. In C. Grant \& M. L. Gomez (Eds.), Campus and classroom: Making schooling multicultural (2nd ed., pp. 31-45). Upper Saddle River: Prentice Hall.

Giroux, H. (2011a). On critical pedagogy. New York: Bloomsbury.

Giroux, H. (2011b). Once more with conviction: Defending higher education as a public good. Qui Parle: Critical Humanities and the Social Sciences, 20(1), 117-135.

Giroux, H. (2013). Neoliberalism's war against teachers in dark times. Cultural Studies $<=>$ Critical Methodologies, 13(6), 458-468.

Gonzalez, G. (1996). Chicano educational history: A legacy of inequality. Humboldt Journal of Social Relations, 22(1), 43-56.

Grande, S. (2004). Red pedagogy: Native American social and political thought. Lanham: Rowman \& Littlefield.

Grant, C., \& Sleeter, C. (2011). Doing multicultural education for achievement and equity (2nd ed.). New York: Routledge.

Greene, M. (1978). Wide awakeness and the moral life. In M. Greene (Ed.), Landscapes of learning (pp. 42-52). New York: Teachers College Press.

Greene, M. (2000). Releasing the imagination: Essays on education, the arts and social change. San Francisco: Jossey Bass.

Greer, C. (1972). The great school legend: A revisionist interpretation of American public education. New York: Basic Books.

Harvey (2005/2010). A brief history of neoliberalism. Oxford: Oxford University Press.

Hirsch, E. D., Jr. (1996). The schools we want and why we don't have them. The Schools we want and why we don't have them. New York: Doubleday.

James, W. (1899). Talks to teachers on psychology and to students on some of life's ideals. New York: Henry Holt.

James, W. (1907/1963). Pragmatism and other essays. New York: Washington Square Press.

Kincheloe, J. L. (2008). Critical pedagogy primer (Vol. 1). New York: Peter Lang.

King, J. (2000). A moral choice. Teaching Tolerance Magazine, 18, 14-15.

King, J. (2015). Dysconscious racism, Afrocentric praxis and education for freedom: Through the years I keep on toiling. New York: Routledge.

Klein, M. (2003). Alternative curriculum conceptions and designs. In A. Orenstein, L. BeharHorenstein, \& F. Pajak (Eds.), Contemporary issues in curriculum (3rd ed., pp. 20-25). Boston: Allyn \& Bacon.

Kliebard, H. M. (2004). The struggle for the American curriculum, 1893-1958 (3rd ed.). New York: Taylor and Francis.

Kozol, J. (2005). The shame of the nation: The restoration of Apartheid schooling in America. New York: Random House.

Ladson-Billings, G. (1995). Toward a theory of culturally relevant pedagogy. American Educational Research Journal, 32(3), 465-491.

Ladson Billings, G. (2006). From the achievement gap to the educational debt: Understanding achievement in US schools. Educational Researcher, 35(7), 3-12.

Lippman, W. (1910). An open mind: William James remembered. http://www.nytimes.com/learning/general/onthisday/bday/0111.html 
Loewen, J. W. (2008). Lies my teacher told me: Everything your American history textbook got wrong. New York: New Press.

May, P., \& Sleeter, C. (2010). Introduction. In P. May \& C. Sleeter (Eds.), Critical multiculturalism: Theory and praxis (pp. 1-16). New York: Routledge.

McLaren, P. (1995). Critical pedagogy and predatory culture: Oppositional politics in a postmodern era. Hove: Psychology Press.

Miel, A. (1961). Creativity in teaching: Invitations and instances. Belmont: Wadsworth Publishing.

Montessori, M. (2013). A critical consideration of the new pedagogy in its relation to modern science. In D. J. Flinders \& S. J. Thornton (Eds.), The curriculum studies reader (4th ed., pp. 19-31). New York: Routledge.

Padgham, R. (1988). Correspondences: Contemporary curriculum theory and twentieth century art. In W. Pinar (Ed.), Contemporary curriculum discourses (pp. 359-379). Scottsdale: Gorsuch Scarisbick.

Patri, A. (1917). A schoolmaster of the great city. New York: Macmillan.

Perlmann, J. (1988). Ethnic differences: Schooling and social structure among the Irish, Italians, Jews and Blacks in an American City, 1880-1935. Cambridge: Cambridge University Press.

Pinar, W. (2004). What is curriculum theory? Mahwah: Lawrence Erlbaum.

Portes, A., \& Zhou, M. (1999). The new second generation: Segmented assimilation and its variants. In N. R. Yetman (Ed.), Majority and minority: The dynamics of race and ethnicity in American life (6th ed., pp. 348-362). Boston: Allyn \& Bacon.

Portes, A., Fernández-Kelly, A., \& Haller, W. (2005). Segmented assimilation on the ground: The new second generation in early adulthood. Ethnic and Racial Studies, 28(November), $1000-1040$.

Ravitch, D. (2014). Reign of error: The hoax of the privatization movement and the danger to America's public schools. New York: Vintage Books.

Reyes-Guerra, D., \& Bogotch, I. (2012). Curriculum inquiry as a transformative leadership skill. In C. Shields (Ed.) Transformative leadership: A reader (Chapter 10, pp. 137-154) New York: Peter Lang Publishers.

Robinson, K. (2006). Do schools kill creativity? TED 2006. Available at: http://www.ted.com/ talks/ken_robinson_says_schools_kill_creativity?language=en

Rose, M. (2011). The mismeasure of teaching and learning: How contemporary school reform fails the test. Dissent (Spring), 32-38.

Sadker, M. P., \& Sadker, D. (2000). Teachers, schools and society. Boston: McGraw Hill.

Seel, H. (1999). 'Allgemeine Didaktik' ('General Didactics') and 'Fachdidaktik' ('Subject Didactics'). Hudson, B., Buchberger F., Kansanen P., Seel H. Didaktik/Fachdidaktik as Science(-s) of the teaching profession? TNTEE Publications, Umea, 2(1), 85-93.

Shields, C. (2014). Leadership for social justice education: A critical transformative approach. In I. Bogotch \& C. Shields (Eds.), The international handbook of educational leadership and social (in)justice (pp. 323-340). Dordrecht: Springer.

Sleeter, C. (2015). Deepening social justice teaching. Journal of Language and Literacy Education [Online]. Retrieved from http://jolle.coe.uga.edu/.

Spring, J. (2010/2013). Deculturalization and the struggle for equality (6th ed.). Boston: McGraw-Hill.

Stack, S. (2004). Elsie Ripley Clapp (1879-1965): Her life and the community school. New York: Peter Lang. 
Tyack, D. (1974). The one best system: A history of American urban education. Cambridge: Harvard University Press.

Tyler, R. W. (1949). Basic principles of curriculum design. Chicago: The University of Chicago Press, 150, 6.

Woodson, C. G. (1933). The mis-education of the Negro. Trenton: Africa World Press.

Zinn, H. (1980/1988). http://zinnedproject.org/about/howard-zinn/

Open Access This chapter is licensed under the terms of the Creative Commons Attribution 4.0 International License (http://creativecommons.org/licenses/by/4.0/), which permits use, sharing, adaptation, distribution and reproduction in any medium or format, as long as you give appropriate credit to the original author(s) and the source, provide a link to the Creative Commons license and indicate if changes were made.

The images or other third party material in this chapter are included in the chapter's Creative Commons license, unless indicated otherwise in a credit line to the material. If material is not included in the chapter's Creative Commons license and your intended use is not permitted by statutory regulation or exceeds the permitted use, you will need to obtain permission directly from the copyright holder.

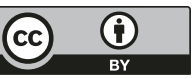

